\title{
Binarna i ternarna relacja uczestników procesu diagnostyczno-terapeutycznego w logopedii
}

\begin{abstract}
Monika Kaźmierczak, Binarna i ternarna relacja uczestników procesu diagnostyczno-terapeutycznego w logopedii [Binary and Ternary Relation between Participants of the Diagnostic and Therapeutic Process in Speech-language Pathology]. Interdyscyplinarne Konteksty Pedagogiki Specjalnej, nr 20, Poznań 2018. Pp. 143-159. Adam Mickiewicz University Press. ISSN 2300-391X. DOI: 10.14746/ikps.2018.20.07

The article points out that the problem of the main binary relation in speechlanguage therapist (therapist-patient) and the interrelated relationship (speechlanguage therapist-patient-family/carer) should be addressed with respect to dialogue personalization, respecting the autonomy of each participant in speechlanguage therapy as well as the specificity of the primary group (family) and secondary (organizational, contractual). The sequence of appropriate interactions, that is, the interactions of the main actors of the diagnostic and therapeutic process, can transform into a lasting relationship and thereby influence the progress in speechlanguage therapy and the quality of the patient's life, if personal contacts and language announcements are reciprocated with kindness, respect and willingness partner collaboration.
\end{abstract}

KEY WORDS: speech-language therapist, patient, family, carer, binary relation, ternary relation 


\section{Wprowadzenie}

Przemiany cywilizacyjne oraz zmieniający się model życia społeczno-kulturowego motywują przeobrażenia celów i roli logopedii we współczesnym świecie. To nauka, którą zajmuje językowy obraz świata, a w szczególny sposób biologiczne uwarunkowania języka i zachowań językowych1․ Różne ujmowanie logopedii - jako nauki multi-, inter- czy transdyscyplinarnej ${ }^{2}$ - wynika z jej przedmiotu oraz z konieczności angażowania $\mathrm{w}$ opiekę nad pacjentem $\mathrm{z}$ zaburzeniami mowy specjalistów innych dziedzin, m.in.: psychologów, pedagogów, terapeutów SI, lekarzy (audiologów, ortodontów, neurologów, neurochirurgów, foniatrów, psychiatrów), fizjoterapeutów, wychowawców przedszkolnych czy nauczycieli nauczania wczesnoszkolnego. Stanowią oni ważne ogniwo w identyfikacji pacjentów wymagających pomocy logopedycznej, mogą też zapewnić niezbędną fachową pomoc i dodatkowe wsparcie podczas terapii zaburzeń mowy. Niezwykle istotny wpływ na postępowanie logopedyczne mają też osoby stale zajmujące się pacjentem i towarzyszące mu w codziennych czynnościach - członkowie rodziny (np. rodzice, współmałżonkowie, dzieci, wnuki) lub wyspecjalizowani opiekunowie niesamodzielnych pacjentów.

Pomoc uwzględniająca wieloaspektowe potrzeby pacjenta odnosi się do sfery zachowań językowych w wymiarze jednostkowym, współtworzących osobową indywidualność oraz do interakcji językowej, która dotyczy zachowań budujących każdą, nawet najmniejszą wspólnotę ${ }^{3}$ czyli zespół osób powiązanych różnego typu

${ }^{1}$ S. Grabias, Teoria zaburzeń mowy. Perspektywy badań, typologie zaburzeń, procedury postępowania logopedycznego, [w:] Logopedia. Teoria zaburzeń mowy, red. S. Grabias, M. Kurkowski, Wydawnictwo UMCS, Lublin 2014, s. 32.

2 Por. S. Michalik, Transdyscyplinarność logopedii - między metodologiczna koniecznościa a teoretyczna utopia, [w:] Metodologia badań logopedycznych z perspektywy teorii i praktyki, red. S. Milewski, E. Czaplewska, Harmonia Universalis, Gdańsk 2015, s. 32-46.

3 S. Grabias, Teoria zaburzeń mowy. Perspektywy badań, typologie zaburzeń, procedury postępowania logopedycznego, [w:] Logopedia. Teoria zaburzeń mowy, red. S. Grabias, M. Kurkowski, Wydawnictwo UMCS, Lublin 2014, s. 17. 
relacjami. W toku postępowania diagnostyczno-terapeutycznego oddziaływanie dotyczy głównie relacji binarnej: pacjenta (indywidualności) i logopedy (znawcy przedmiotu, terapeuty zaburzeń mowy). Już od pierwszego spotkania budowanie więzi powinno opierać się na dialogicznej relacji ${ }^{4}$, na wzajemnym szacunku, respektowaniu autonomii drugiego człowieka i obustronnej autentyczności. Sprzyja temu przyjazna atmosfera i właściwa organizacja spotkań uwzględniająca indywidualne potrzeby i ograniczenia obu podmiotów. Jednak wśród pacjentów logopedycznych znaczny odsetek stanowią dzieci oraz dorośli wymagający opieki, dlatego niejednokrotnie można zaobserwować przekształcenie relacji binarnej pacjent - logopeda w układ trójstronny: pacjent - logopeda rodzina/opiekun. W każdym przypadku podtrzymywanie prawidłowych relacji, tj. działań, które podmiot inicjuje lub podejmuje, którym podlega i których skutki przyjmuje ${ }^{5}$, wymaga przyjęcia właściwej strategii motywacyjnej i zaangażowania się w bieżącą aktywność. Ciąg właściwych interakcji, czyli wzajemnego oddziaływania głównych podmiotów procesu diagnostyczno-terapeutycznego, może przeobrazić się w trwałą relację, a tym samym wpływać na postępy $w$ terapii zaburzeń mowy oraz funkcjonowanie człowieka na co dzień.

Wiedza o współpracy logopedy z pacjentem i jego najbliższym otoczeniem nadal jest niewystarczająca ${ }^{6}$, a refleksja wymaga pogłębienia. Relacje uczestników procesu diagnostyczno-terapeutycznego odnosi się przede wszystkim do nadrzędnego celu praktycznego terapii logopedycznej, czyli niwelowania zaburzeń mowy oraz usprawniania procesu interakcji językowej, a osiągnięcie go uzależ-

4 Por. M. Kaźmierczak, Dialogiczna relacja logopedy i pacjenta, [w:] Problemy badawcze $i$ diagnostyczne w logopedii, red. I. Jaros, R. Gliwa, Wydawnictwo UŁ, Łódź 2016, s. 9-17.

${ }^{5} \mathrm{M}$. Gogacz, Człowiek i jego relacje (materiaty do filozofii człowieka), ATK, Warszawa 1985 , s. 33.

${ }^{6}$ A. Banaszkiewicz, A. Walencik-Topiłko, Model wspótpracy logopedy z otoczeniem pacjenta - założenia teoretyczne i rozwiazania praktyczne, [w:] Terapia logopedyczna, red. D. Baczała, J. Błeszyński, Wyd. Nauk. UMK, Toruń 2014, s. 86. 
nia od możliwości pacjenta, jego aktywności poznawczej oraz profesjonalizmu logopedy ${ }^{7}$. Rzadziej i w znacznie mniejszym stopniu zwraca się uwagę na wartość samego spotkania osób, które realizują w ten sposób potrzebę bycia z innym, kontaktu, a dzięki wzajemnym relacjom personalnym mogą krystalizować indywidualną tożsamość oraz realizować się w dialogu i przez dialog.

\section{Zapoczątkowanie relacji logopedy i pacjenta}

Zgodnie z zasadą dialogiczną, człowiek konstytuuje siebie dzięki spotkaniu z Ty (relacja symetryczna - Martin Buber), w odniesieniu do Innego (relacja asymetryczna - Emmanuel Levinas), ale też otaczającej rzeczywistości ${ }^{8}$. Taka relacja wiąże się ze wspólnotą działań i postaw (m.in. współ-bycie, współ-odczuwanie, współ-poznanie), w której jest respektowana godność każdego uczestnika sytuacji dialogicznej9. Relacja osobowa wyklucza reifikację człowieka, dominację czy podporządkowanie którejkolwiek ze stron dialogu10, dlatego jest czymś więcej niż tylko transmisją informacji (model transmisyjno-informacyjny komunikacji), werbalnym przekazywaniem bądź egzekwowaniem zapamiętanych treści.

Podczas spotkania, nawet jeszcze przed nawiązaniem werbalnego kontaktu, pacjent i logopeda oswajają się z obecnością nowo poznanego człowieka, przyzwyczajają do siebie, a troska o trwanie nawiązywanej relacji staje się ważnym zadaniem obu stron. Może to zaistnieć, jeśli żaden z uczestników nie dostrzeże zagrożenia ze

${ }^{7}$ M. Sochoń, E. Krajewska-Kułak, J. Śmigielska-Kuzia, Oczekiwania rodziców dzieci w wieku przedszkolnym wobec logopedy, "Pielęgniarstwo i Zdrowie Publiczne” 2016, nr 2, s. 110.

8 Por. T. Gadacz, Historia filozofii XX wieku. Nurty, t. 2 Neokantyzm, filozofia egzystencji, filozofia dialogu, Wydawnictwo Znak, Kraków 2009 s. 506 i n.

${ }_{9}^{9}$ B. Kiereś, Wspótczesna pedagogika a problem godności człowieka, [w:] Personalistyczny wymiar filozofii wychowania, red. A. Szudra i K. Uzar, Wydawnictwo KUL Lublin. 2009, s. 188.

10 W. Chudy, Pedagogia godności. Elementy etyki pedagogicznej, Wydawnictwo KUL, Lublin 2009, s. 209-213 
strony drugiej osoby, jeśli zaufa i wyczuje dobre intencje: pacjent życzliwość i chęć pomocy ze strony logopedy, logopeda gotowość pacjenta do (współ)pracy nad zaburzeniem mowy. Za manifestację intencji nadawcy uznaje się różne zachowania niewerbalne i werbalne, które służą negocjowaniu i budowaniu znaczeń w interakcji, także wyrażaniu emocji lub potrzeb mentalnych i komunikacyjnych uczestników dialogu. U pacjentów logopedycznych różne elementy kodu mogą być zaburzone, a ich interpretacja przez terapeutę utrudniona.

Doświadczenia z wcześniej prowadzonego postępowania logopedycznego zawsze mają wpływ na nawiązywanie relacji - kiedy były zaburzone lub przyjmowały formę nieuwzględniającą podmiotowości pacjenta (np. konieczności biernego poddawania się świadomego pacjenta mechanicznym czynnościom bądź autorytarnym decyzjom logopedy ${ }^{11}$, powodują jego nieufność i wytwarzają dystans, który trzeba stopniowo niwelować. Gdy logopeda oddziałuje na pacjenta i otwiera się na takie samo oddziaływanie, zachodzi między nimi relacja życzliwości, która wyklucza bezwzględną dominację, agresję czy destrukcyjne działania. Odniesienie jako podstawowa relacja międzyludzka, wynikająca $\mathrm{z}$ istnienia każdego podmiotu, wyraża się we wzajemnym szacunku i zaufaniu. Uczestnicy prawdziwego dialogu $\mathrm{w}$ logopedii zorientowani są na przeciwdziałanie uniformizmowi, na maksymalizowanie rozwoju jednostki. Wiąże się to $\mathrm{z}$ ujęciem obrazu pacjenta jako indywidualności, autonomicznego bytu, co pozwala uniknąć relatywizmu i autorytaryzmu.

Również terapeuta nie jest tylko biernym słuchaczem czy instruktorem, ale zaangażowanym partnerem, który w interakcji przyjmuje postawę akceptującą. By mógł tego dokonać, najpierw

11 T. Szasz i M.H. Hollender wymienione typy interakcji pacjent-lekarz nazwali odpowiednio: kierowanie-współpraca oraz aktywność-bierność, natomiast E. i L. Emanuel określili jako: informacyjny i paternistyczny; J. Barański, Interakcja lekarzpacjent, [w:] Zdrowie i choroba. Wybrane problemy socjologii medycyny, red. J. Barański, W. Piątkowski, Wydawnictwo Atut, Wrocław 2002, s. 159; A. Kowalska i in., Etyczne aspekty komunikacji pacjent - lekarz, „Medycyna Ogólna” 2010, nr 16, s. 428. 
musi mieć ugruntowaną tożsamość jednostkową, być osobą otwartą na nowe wyzwania i drugiego człowieka. Ze względu na autorytet epistemiczny (oparty na kompetencjach) oraz deontyczny solidarności (przyjmowanie kierowniczej roli w osiąganiu wspólnego celu $)^{12}$, w tym układzie logopedę uznaje się za podmiot będący przyczyną asymetrycznej relacji, przez którą i dzięki której poprawie może ulec m.in. jakość zachowań językowych. U pacjenta poszukuje się głównie skutków podejmowanych działań, jednak wzajemność oznacza, że interakcję może inicjować również pacjent, jeśli nie został objęty pasywną terapią. Współuczestnictwo (Thomas Szasz, Marc Hollender), inaczej wspólne naradzanie się (Ezekiel i Linda Emanuel) ${ }^{13}$ charakteryzuje się tym, że specjalista jasno przedstawia możliwe strategie postępowania, aktywnie słucha uwag pacjenta, doradza mu i omawia każdy przewidywany etap pracy przed zbudowaniem programu terapii. Dzięki partnerstwu i wzajemnej, dwukierunkowej komunikacji, pacjent ma większą motywację do realizacji ustalonych celów, których jest świadomy, wyraźniej angażuje się w zindywidualizowaną terapię, częściej inicjując dialog i działania, gdyż wie, czego spodziewać się podczas kolejnych spotkań. Przyjmuje też współodpowiedzialność za ostateczne efekty procesu terapeutycznego.

Samą organizacją postępowania diagnostyczno-terapeutycznego zajmuje się logopeda, który przy podejmowaniu decyzji o jego formie bierze pod uwage typ zdiagnozowanego zaburzenia mowy, wiek pacjenta, jego sytuację rodzinną i prawną, stan psychofizyczny itd. Ze względu na negatywne doświadczenia czy obawy pacjenta, pierwsze spotkania mogą wymagać obecności rodzica/opiekuna (w placówce przedszkolnej kolegi z grupy lub wychowawcy),

12 J.M. Bocheński, Co to jest autorytet?, [w:] J.M. Bocheński, Logika i filozofia. Wybór pism, tłum. i opr. J. Parys, Warszawa 1993, s. 242, 293.

13 J. Barański, Interakcja lekarz-pacjent, [w:] Zdrowie i choroba. Wybrane problemy socjologii medycyny, red. J. Barański, W. Piątkowski, Wydawnictwo Atut, Wrocław 2002, s. 161; A. Kowalska i in., Etyczne aspekty komunikacji pacjent - lekarz, „Medycyna Ogólna" 2010, nr 16, s. 428. 
a nawet czynnego udziału trzeciej osoby w ćwiczeniach. Kiedy niezbędna jest obecność trzeciego uczestnika spotkań (rodzica, dziadka, współmałżonka, pielęgniarki, opiekuna i in.), istnieje konieczność dookreślenia jego zadań i roli, uświadomienia współodpowiedzialności za przebieg terapii i komunikację pacjenta. U podstaw nowej relacji nie leży prosta synteza tego, co indywidualne i tego, co społeczne. Wymagane jest zachowanie podmiotowości każdej osoby, ale też specyfiki grup pierwotnej (rodzinnej) oraz wtórnej (o charakterze organizacyjnym, umownym). W przypadku samodzielnych pacjentów z czasem rodzic/opiekun stopniowo ogranicza swoją aktywność podczas terapii, staje się obserwatorem lub - w porozumieniu z logopedą oraz dzieckiem/podopiecznym - częściowo bądź w ogóle rezygnuje z obecności w gabinecie.

Respektowanie autonomii jednostek i odrębności grupy pierwotnej wiąże się z poszanowaniem przez logopedę odmiennych norm, wzorów postępowania pacjenta i jego rodziny. Ale podczas budowania trójstronnej relacji należy brać pod uwage również podmiotowość logopedy czy wyspecjalizowanego opiekuna, wyznawane przez nich wartości oraz zasady. Dopiero uwzględnienie pluralizmu kulturowego, przestrzeganie przyjętych norm oddziaływań językowych i kulturowych może sprawić, że strategie wsparcia i uznania zmienią się w szczere, prawdziwe relacje, dające trwałe podstawy dla współdziałania, które jest jednym z teleologicznych założeń procesu diagnostyczno-terapeutycznego w logopedii.

Wzajemna życzliwość, akceptacja podmiotów procesu diagnostyczno-terapeutycznego w logopedii wynikają zatem $\mathrm{z}$ samej obecności innych osób, poczucia współodpowiedzialności za drugiego człowieka. Chęć poznania wymaga wzajemnego otwarcia na siebie i wiary w powodzenie podejmowanych działań, co może nastąpić dzięki zaufaniu, jakim obdarzają się ludzie. Relacje osobowe w wymiarze społecznym, czyli orientowanie się na siebie i wzajemne oddziaływanie członków wspólnoty, charakteryzuje wsparcie społeczne zarówno w wymiarze emocjonalnym, wartościującym (znaczenie człowieka w grupie), instrumentalnym (dostarczanie pomocy, świadczenie usług), jak informacyjnym (rady, przekazy- 
wanie danych i wiadomości) ${ }^{14}$. Adekwatne wsparcie, wynikające z sygnałów i komunikatów pozwalających człowiekowi wierzyć, że jest otoczony życzliwymi ludźmi oraz opieką w zakresie zaburzeń mowy, sprzyja normalizacji życia rodzinnego, rozwojowi psychospołecznemu pacjenta i poprawie jakości jego zachowań językowych na co dzień.

\section{Relacje w interakcji językowej}

Według dialogików, budowanie osobowej relacji Ja - Ty/Inny podczas spotkania dotyczy kategorii dobra. Jednak rehabilitacji sfery poznania w dialogu podjął się m.in. Hans-Georg Gadamer, który podkreślał jedność prawdy i dobra, logosu i ethosu ${ }^{15}$. Za pewnego rodzaju pomost między niepoznawalnymi podmiotami można uznać dialog rozumiany jako rozmowa. Słowny przekaz jest istotny, gdyż łączy rozmówców używających takiego samego języka i funkcjonujących we wspólnej tradycji, ale powstrzymujących się od dążenia do uniformizacji i asymilacji interlokutora. Werbalizacja oraz wymiana myśli czy uczuć, jak również konfrontacja opinii w dialogu przebiega w sposób dynamiczny - jest wynikiem manifestacji osobowości, możliwości i kondycji psychofizycznej rozmówców, zależy też od okoliczności zewnętrznych. Postrzeganie Ty/Innego jako bytu niepoznawalnego wyklucza uprzedmiotowienie i redukowanie człowieka do zaledwie wyobrażenia o nim. Zasady współfunkcjonowania dotyczą zarówno rodzącej się relacji i jej wpływu na terapię logopedyczną, odniesienia każdego z podmiotów do samego siebie oraz do współrozmówcy, jak i do interakcji językowej.

Wzajemność wymaga autentyczności wypowiedzi, spójności komunikatów werbalnych z mową ciała oraz mimiką twarzy. Do-

${ }^{14}$ K. Kmiecik-Baran, Skala wsparcia społecznego. Teoria i właściwości psychometryczne, "Przegląd Psychologiczny” 1995, t. 38, nr 1, s. 202.

15 P. Sznajder, Logos wyłaniajacy się z rozmowy. Inny a prawda w dialogu w filozofii Hansa-Georga Gadamera, „Estetyka i Krytyka” 2012, nr 2 s. 197. 
bór przekazu adekwatnego do sytuacji terapeutycznej pozwala wziąć odpowiedzialność za własne słowo oraz za niemówienie, które daje czas na podjęcie decyzji o udzieleniu bądź nie odpowiedzi na pytanie, zareagowaniu na kontakt inicjowany przez drugiego człowieka. Pozostawiony pacjentowi wybór dotyczący momentu podjęcia rozmowy z terapeutą to wyraz szacunku i dla rozmówcy, i dla siebie, zrozumienia trudności komunikacyjnych nie tylko w sferze fizycznej, ale również psychicznej, emocjonalnej. Podkreślane $\mathrm{w}$ personalizmie dialogowym odpowiedzialne korzystanie z wolności wymaga empatii, zrozumienia i zaakceptowania osobowości współrozmówcy, dzięki czemu między terapeutą a pacjentem może wytworzyć się więź, zaistnieć pewnego rodzaju sojusz ułatwiający osiąganie kolejnych celów związanych z poprawą jakości interakcji językowej. Budowaniu wzajemnego zaufania sprzyjają również jasne i zaaprobowane przez obie strony zasady, według których organizowane są spotkania. Taka transparentność jest istotna, służy bowiem świadomemu i aktywnemu udziałowi w terapii ${ }^{16}$.

Prawdziwy dialog wymaga zaakceptowania konieczności wymiany ról nadawcy-odbiorcy komunikatu. $\mathrm{W}$ rozmowie to nadawca decyduje, jaką prawdę o sobie i świecie przekazuje, na ile pozwala sobie wejść w relację z drugim człowiekiem. Dzięki rozmowie następuje manifestacja własnych pragnień, ale też wymiana myśli z poszanowaniem odmiennej opinii i postawy drugiego człowieka. W relacji interpersonalnej język pośredniczy w budowaniu wyobrażenia o drugiej osobie, staje się narzędziem (po)rozumienia, które wymaga przekroczenia własnego horyzontu poznania, otwarcia na inny punkt widzenia, wyzbycia się uprzedzeń bez rezygnacji z własnego stanowiska czy chęci zdominowania interlokutora, co oznaczałaby wprowadzenie przedmiotowej relacji. Założeniem interakcji językowej nie jest pełne rozpoznanie drugiego człowieka i wyeliminowanie różnic dzielących uczestników rozmowy. Choć w logope-

${ }^{16}$ G. Jastrzębowska, O. Pęc-Pękala, Metodyka ogólna diagnozy i terapii logopedycznej, [w:] Logopedia. Pytania i odpowiedzi, red. G. Jastrzębowska i T. Gałkowski, Wydawnictwo UO, Opole 2003, s. 327. 
dycznym dialogu relacja poznania wynika $\mathrm{z}$ afirmowania drugiej osoby, to odnosi się ona do układu Ja - To oraz phronesis ${ }^{17}$, praktycznej wiedzy z zakresu przedmiotu, czyli formy i treści językowego oraz pozajęzykowego komunikatu.

Dialog nie jest jednak zwykłą rozmową, podczas której uczestnicy koncentrują uwagę na umiejętnościach technicznych. Sztuka dialogu to poszukiwanie autorskich sposobów nawiązywania kontaktów interpersonalnych, prowadzących do przekształcających oddziaływań, w tym zwiększenia wewnętrznej motywacji do pracy nad zaburzeniem mowy i woli rozmowy. Nawet w asymetrycznym dialogu, dzięki zaufaniu do autorytetu oraz wspieraniu naturalnego potencjału pacjenta, praca $\mathrm{w}$ gabinecie logopedycznym zorientowana jest głównie na rozwój osoby, nie tylko program terapii, który niejednokrotnie wymaga krytycznego przemyślenia, weryfikacji i adaptacji do aktualnych potrzeb. W sytuacji terapeutycznej trudno szczegółowo nakreślić i przewidzieć przebieg dialogu. Refleksyjna (samo)świadomość logopedy i pacjenta uwzględnia nieprzewidywalność udzielanych odpowiedzi, dopuszcza problematyczność zaistniałych albo prowokowanych sytuacji komunikacyjnych, w których mogą występować wypowiedzi niejednoznaczne, szczątkowe bądź niedopowiedzenia, charakterystyczne dla żywej mowy.

Wzajemny szacunek i partnerstwo wymagane są również $\mathrm{w}$ relacji logopedy z uczestnikami diagnozy i terapii logopedycznej, którzy pełnią funkcję wspierającą, dodatkową. Niezbędne pacjentowi wsparcie rodziny wynika ze stosunku najbliższego otoczenia do człowieka i jest wyrazem bieżących relacji, nie zaś działań okazjonalnych, podejmowanych w losowych sytuacjach. Szczególnie po zakończeniu terapii rodzic staje się głównym partnerem $\mathrm{w}$ dialogu z logopedą, z którym omawia przebieg ćwiczeń, postępy czy zadania do pracy $\mathrm{w}$ domu oraz często dzieli się spostrzeżeniami dotyczącymi codziennego funkcjonowania dziecka. Jeśli mały pacjent jest obecny, lecz nie uczestniczy czynnie w rozmowie, nie może być traktowany w sposób przedmiotowy.

17 Arystoteles, Etyka nikomachejska, tłum. D. Gromska, PWN, Warszawa 1982, 1140 a $24-1142$ b 31. 
$\mathrm{W}$ trakcie postepowania logopedycznego istotne jest zaspokajanie potrzeb emocjonalnych pacjenta i realizowanie przez rodzinę funkcji emocjonalno-społecznych. Może odbywać się to poprzez niewymuszone, spontaniczne wykazywanie zainteresowania interakcją komunikacyjną na co dzień, jak również pełnienie funkcji ochronnej i wspierającej poprzez działania zaradcze albo interwencyjne $\mathrm{w}$ wyjątkowej sytuacji18 - taką jest zdiagnozowanie zaburzenia mowy i konieczność podjęcia terapii logopedycznej. Zaspokojenie potrzeb bliskości, więzi czy zainteresowania, daje pacjentowi poczucie bezpieczeństwa i oparcia. Jakość trójstronnej relacji rodzina - logopeda - pacjent $\mathrm{w}$ dużej mierze zależy więc od postaw nie tylko terapeuty, ale też bliskich, którzy sami wymagają wsparcia w nowej sytuacji.

Rodzice przyjmują względem dziecka różne postawy: pozytywne (akceptacji, autonomii) lub negatywne (odrzucenia, nadmiernego wymagania, nadmiernego ochraniania, niekonsekwencji) ${ }^{19}$. Ze względu na własne doświadczenia i światopogląd mają różne podejście do terapii zaburzeń mowy dziecka: albo postrzegają ją przez pryzmat własnych doświadczeń z dzieciństwa, albo są sceptyczni, a ukierunkowywani dopiero szukają sensu podjęcia działań pomocowych, gdyż nigdy nie zetknęli się z terapeutą mowy i głosu, albo są otwarci i chętni do współpracy, podobnie jak w przypadku każdej innej specjalistycznej konsultacji dziecka, albo ignorują zalecenia i nie zgłaszają się do logopedy. Już podczas pierwszego kontaktu terapeuta powinien pamiętać, że każdy z członków grupy pierwotnej przychodzi z ustalonymi celami, oczekiwaniami i przekonaniami, które oparł na dostępnej wiedzy na temat zaburzeń mowy oraz postępowania logopedycznego, z postawą względem terapeuty wynikającą z przekonania o roli i zadaniach pacjenta. Odmienne wyobrażenia, a także założenia logopedy oraz pacjenta i rodzica

${ }^{18}$ G. Filipiak, Funkcja wsparcia spotecznego w rodzinie, „Roczniki Socjologii Rodziny" 1999, R. XI, s. 135.

${ }^{19} \mathrm{M}$. Plopa, Więzi w matżeństwie i rodzinie. Metody badań, Oficyna Wydawnicza „Impuls", Kraków 2005, s. 235-238. 
względem terapii mogą szczególnie na początku utrudniać nawiązanie prawdziwej trójstronnej relacji, jednak warto podjąć ten trud. Rodzice małego pacjenta odgrywają niezwykle istotną rolę wspierającą, ale są też cennym źródłem informacji, decydują o wyjawieniu intymnych szczegółów z życia i o stanie zdrowia pacjenta, stają się głównymi odbiorcami komunikatów o funkcji informacyjno-diagnostycznej, często również perswazyjnej, których celem jest wprowadzenie pożądanych zmian postawy u dziecka. Odpowiadają za wykonywanie ćwiczeń $\mathrm{w}$ domu, eliminowanie nawyków negatywnie wpływających na mowę, co niekiedy wymaga modyfikacji zachowań i postaw wszystkich domowników. Partnerstwo, jako podstawa relacji logopedy i rodzica, staje się jednym z ważniejszych czynników warunkujących efekty pracy logopedycznej z małym pacjentem ${ }^{20}$.

$\mathrm{W}$ rodzinie występują przede wszystkim relacje realne, takie jak przyjaźń, życzliwość, zaufanie, wiara w drugiego człowieka czy akceptacja. Mogą one również zaistnieć w gabinecie logopedycznym, gdyż nie są zależne od decyzji bądź poznania. Jednak w grupie o charakterze organizacyjnym zdarza się, że relacje realne są dominowane przez myślne, czyli zachodzące pomiędzy osobami i ich wytworami m.in. rozmowy, ideologie ${ }^{21}$. Czynności podejmowane przez logopedę są częścią systemowego działania sieci instytucji pomocowych zatrudniających specjalistów, w tym także terapeutów mowy i głosu. Sprowadzanie człowieka do rangi tylko pacjenta, klienta, interesanta czy petenta sprawia, że terapia logopedyczna jest zorientowana na zaburzenie mowy (To), nie zaś pacjenta jako osoby z zaburzeniem (Ty/Inny).

Nie mniej istotna jest relacja logopedy z opiekunem profesjonalnie zajmującym się nie $\mathrm{w}$ pełni samodzielnym pacjentem. Wyspecja-

${ }^{20}$ M. Sochoń, E. Krajewska-Kułak, J. Śmigielska-Kuzia, Oczekiwania rodziców dzieci w wieku przedszkolnym wobec logopedy, "Pielęgniarstwo i Zdrowie Publiczne" 2016, nr 2, s. 114; K. Węsierska, Profilaktyka logopedyczna w praktyce edukacyjnej, t. 1, red. K. Węsierska, Wydawnictwo UŚ, Katowice 2012, s. 41.

${ }^{21} \mathrm{M}$. Gogacz, Człowiek i jego relacje (materiaty do filozofii człowieka), Akademia Teologii Katolickiej, Warszawa 1985, s. 133. 
lizowani opiekunowie reprezentują instytucje udzielające pomocy czasowo, w określonych przypadkach i w wytyczonym zakresie 22 , dlatego $\mathrm{z}$ reguły są mniej zaangażowani emocjonalnie, oczekują przede wszystkim instruktażu i profesjonalnych porad dotyczących pracy $\mathrm{w}$ celu eliminowania lub ograniczania zaburzenia. Od tej grupy zawodowej oczekuje się jednak nie tylko fachowej pomocy i rzetelnej informacji o przebiegu leczenia, efektywności stosowanych środków i zabiegów oraz o postępach w (re)edukacji mowy. Mimo odmiennego niż rodzina postrzegania choroby i związanego $\mathrm{z}$ nią zaburzenia mowy, wyspecjalizowany personel powinien odznaczać się również empatią, zrozumieniem, zapewniać pacjentowi bezpieczeństwo i komfort codziennego funkcjonowania. Sama obecność drugiego człowieka generuje potrzebę zamanifestowania emocji związanych $\mathrm{z}$ terapią - na początku często negatywnych, ale $\mathrm{z}$ czasem $\mathrm{w}$ wielu przypadkach rodzi się chęć inicjowania przez pacjenta pozytywnych kontaktów, również werbalnych.

Problem współpracy logopedy z pacjentem, jego rodziną bądź opiekunem powinien być rozstrzygany $\mathrm{w}$ dialogu i przez dialog, jednak ze względu na posiadaną władzę i wiedzę, rodzina/opiekun oraz logopeda często sami omawiają problematyczne kwestie, podejmują kluczowe decyzje, których celem jest wyobrażane przez nich dobro pacjenta. Jeśli $\mathrm{w}$ trójstronnym układzie autorytet jest wykorzystywany do wywierania presji, a od pacjenta oczekuje się tylko posłuszeństwa i uległości wobec narzuconej strategii postępowania, trudno zakładać dobre relacje interpersonalne, podobnie $\mathrm{w}$ sytuacji, $\mathrm{w}$ której organizator terapii oczekuje bezwzględnego dostosowania się i pokornego realizowania narzuconego planu działań. Zmiana paradygmatu adaptacyjnego na paradygmat terapii podmiotowej umożliwia dookreślanie roli i miejsca każdej z osób $\mathrm{w}$ organizowanej wspólnocie, rozsądny i zgodny z możliwościami podział zadań, jak również zaistnienie prawdziwego dialogu.

${ }^{22}$ G. Filipiak, Funkcja wsparcia społecznego w rodzinie, „Roczniki Socjologii Rodziny" 1999, R. XI, s. 133. 


\section{Zakończenie}

Działania podejmowane w procesie diagnostyczno-terapeutycznym są odpowiedzią na nieprawidłowości w zakresie komunikacji językowej, których etiologii należy szukać w biologicznych, psychicznych oraz społecznych uwarunkowaniach mowy. Nadrzędnym praktycznym celem terapii logopedycznej jest wygaszanie, ograniczanie albo eliminowanie problemów związanych z obserwowanymi zaburzeniami interakcji językowej. Wyznaczają je standardy postępowania, a ostateczną formę poszczególnych etapów dostosowuje się indywidualnie do pacjenta z zaburzeniem mowy.

Istnienie relacji wynikających z kontaktów interpersonalnych można uznać za konstytutywny składnik postępowania logopedycznego, szczególnie w obliczu obserwowanych współcześnie kontaktów społecznych o charakterze przelotnym i bezosobowym. Wrażliwość zarówno rodziny/opiekuna, jak też logopedy na potrzeby pacjenta, wspieranie go $\mathrm{w}$ toku terapii, $\mathrm{z}$ uwzględnieniem ograniczeń, to nie tylko dążenie do uzyskania normy, czyli zestawu cech, kompetencji i umiejętności, które w danym wieku powinien posiadać. Stosowana $\mathrm{w}$ logopedii zasada indywidualizacji ${ }^{23}$ wymaga empatii oraz większej troski o zaadaptowanie strategii postępowania czy etapów pracy do możliwości pacjenta, co wyklucza bezrefleksyjne zmierzanie do założonego celu terapii logopedycznej.

We wzajemnych kontaktach pacjent potrzebuje pomocy i wsparcia, rodzina zrozumienia, a logopeda możliwości jak najlepszego działania w oparciu o posiadane kompetencje i doświadczenie zawodowe. W trójstronnym układzie skuteczna i harmonijna komunikacja sprzyja podziałowi zadań adekwatnemu do możliwości i potrzeb każdego podmiotu, pozwala doprecyzować zasady współpracy, które zaakceptują wszyscy uczestnicy procesu diagnostyczno-terapeutycznego, w znaczący sposób może wpłynąć na późniejsze koordynowanie procedur i weryfikowanie efektów.

${ }^{23}$ G. Jastrzębowska, O. Pęc-Pękala, Metodyka ogólna diagnozy i terapii logopedycznej, [w:] Logopedia. Pytania i odpowiedzi, red. G. Jastrzębowska i T. Gałkowski, Wydawnictwo UO, Opole 2003, s. 327. 
Znane z lekcji metody frontalnego prowadzenia zajęć, weryfikacji i kontroli wyrażonej przez szkolną skalę ocen, w gabinecie logopedycznym powinny być zastępowane współuczestnictwem, współdziałaniem, (auto)kontrolą, a nawet (auto)ewaluacją świadomego pacjenta, który stanowi o własnej aktywności, bierze też współodpowiedzialność za efekty terapii. W sytuacji wewnętrznego konfliktu (pacjent nie chce uczęszczać na terapię, ale wie, że powinien) lub sporu z rodziną/opiekunem, może wystąpić zaprzeczenie własnym uczuciom oraz uległość wobec silniejszego, czyli przenoszenie sytuacji przymusu (np. obowiązek szkolny/nauki, konieczność podporządkowania się przełożonemu) do terapii logopedycznej, która w przypadku świadomych pacjentów powinna być oparta na zasadzie dobrowolnego udziału.

Refleksja dotycząca relacji $\mathrm{w}$ postępowaniu logopedycznym wskazuje konieczność teoretycznych uzasadnień badań empirycznych, lecz ze względu na odmienność i autonomię każdego z podmiotów nie daje możliwości ustalenia jednego paradygmatu, według którego można projektować współdziałania związane z korekcją zaburzeń mowy. Trzeba jednak zauważyć, że humanizacja terapii logopedycznej wynika $\mathrm{z}$ traktowania pacjenta jako osoby, co wymaga podejmowania prób przeciwdziałania zaburzonym relacjom międzyludzkim i nienormatywnym zachowaniom językowym. Za propozycje takie można uznać m.in. zwrot ku filozoficznym i antropologicznym nurtom wieków XX i XXI, w tym nurtowi egzystencjalno-dialogicznemu czy personalizmowi, ujmowanemu jako postawa zorientowana na szacunek wobec drugiego człowieka, który - (samo)świadomy i wolny w decyzjach - może realizować siebie. Co więcej, już w przygotowaniu zawodowym studentów istotne jest wyposażenie przyszłych logopedów w kompetencje komunikacyjne uwzględniające zasady prawdziwego dialogu oraz interakcji językowej, będącej częścią podmiotowych relacji międzyludzkich. W odniesieniu do tych założeń, stosowanym podczas kształcenia, a później w diagnozie i terapii logopedycznej narzędziom, środkom technicznym czy finansowym trzeba przypisać drugorzędną, pomocniczą rolę, choć $\mathrm{w}$ powszechnej świadomości wyznacza się im większe niż realne znaczenie. 


\section{Bibliografia}

Arystoteles, Etyka nikomachejska, tłum. D. Gromska, PWN, Warszawa 1982.

Banaszkiewicz A., Walencik-Topiłko A., Model wspótpracy logopedy z otoczeniem pacjenta - założenia teoretyczne $i$ rozwiąania praktyczne, [w:] Terapia logopedyczna, red. D. Baczała i J. Błeszyński, Wydawnictwo Naukowe UMK, Torun 2014.

Barański J., Interakcja lekarz-pacjent, [w:] Zdrowie i choroba. Wybrane problemy socjologii medycyny, red. J. Barański, W. Piątkowski, Wydawnictwo Atut, Wrocław 2002.

Bocheński J.M., Co to jest autorytet?, [w:] J.M. Bocheński, Logika i filozofia. Wybór pism, tłum. i opr. J. Parys, Wydawnictwo Naukowe PWN, Warszawa 1993.

Chudy W., Pedagogia godności. Elementy etyki pedagogicznej, Wydawnictwo KUL, Lublin 2009.

Filipiak G., Funkcja wsparcia społecznego w rodzinie, „Roczniki Socjologii Rodziny” 1999, R. XI.

Gadacz T., Historia filozofii XX wieku. Nurty, t. 2 Neokantyzm, filozofia egzystencji, filozofia dialogu, Wydawnictwo Znak, Kraków 2009.

Gogacz M., Człowiek i jego relacje (materiały do filozofii człowieka), Akademia Teologii Katolickiej, Warszawa 1985.

Grabias S., Teoria zaburzeń mowy. Perspektywy badań, typologie zaburzeń, procedury postępowania logopedycznego, [w:] Logopedia. Teoria zaburzeń mowy, red. S. Grabias, M. Kurkowski, Wydawnictwo UMCS, Lublin 2014.

Jastrzębowska G., Pęc-Pękala O., Metodyka ogólna diagnozy i terapii logopedycznej, [w:] Logopedia. Pytania i odpowiedzi, red. G. Jastrzębowska i T. Gałkowski, Wydawnictwo UO, Opole 2003.

Kaźmierczak M., Dialogiczna relacja logopedy i pacjenta, [w:] Problemy badawcze $i$ diagnostyczne w logopedii, red. I. Jaros, R. Gliwa, Wydawnictwo UŁ, Łódź 2016.

Kiereś B., Wspótczesna pedagogika a problem godności człowieka, [w:] Personalistyczny wymiar filozofii wychowania, red. A. Szudra i K. Uzar, Wydawnictwo KUL, Lublin 2009.

Kmiecik-Baran K., Skala wsparcia społecznego. Teoria $i$ wtaściwości psychometryczne, „Przegląd Psychologiczny" 1995, t. 38, nr 1.

Kowalska i in., Etyczne aspekty komunikacji pacjent - lekarz, „Medycyna Ogólna” 2010, nr 16.

Michalik S., Transdyscyplinarność logopedii - między metodologiczna koniecznościa a teoretyczna utopia, [w:] Metodologia badań logopedycznych z perspektywy teorii i praktyki, red. S. Milewski, E. Czaplewska, Harmonia Universalis, Gdańsk 2015.

Plopa M., Więzi w matżeństwie i rodzinie. Metody badań, Oficyna Wydawnicza „Impuls", Kraków 2005.

Sznajder P., Logos wyłaniajacy się z rozmowy. Inny a prawda w dialogu w filozofii HansaGeorga Gadamera „Estetyka i Krytyka” 2012, nr 2. 
Binarna i ternarna relacja uczestników procesu diagnostyczno-terapeutycznego 159

Sochoń M., Krajewska-Kułak E., Śmigielska-Kuzia J., Oczekiwania rodziców dzieci w wieku przedszkolnym wobec logopedy, „Pielęgniarstwo i Zdrowie Publiczne” 2016, nr 2.

Węsierska K., Profilaktyka logopedyczna w praktyce edukacyjnej, t. 1, red. K. Węsierska, Wydawnictwo UŚ, Katowice 2012. 